\title{
ORIGIN OF THE LATE ORDOVICIAN LEPIDOCYCLUS BRACHIOPOD FAUNA IN NORTH AMERICA AND ITS BIOGEOGRAPHIC SIGNIFICANCE
}

JIN*, Jisuo, Royal Tyrrell Museum of Palaeontology, P.O. Box 7500, Drumheller; Alberta, Canada, TOJ OY0.

Three rhynchonellid brachiopod genera, Hiscobeccus, Lepidocyclus, and Hypsiptycha, are the most diagnostic elements of the Lepidocyclus fauna of North America in Late Ordovician time. These are characterized by relatively large, strongly biconvex to globular shells with coarse imbricating growth lamellae and, internally, with septiform cardinal processes in brachial valves. Among the three genera, Hiscobeccus appears the earliest, now known from rocks of late TrentonianEdenian age in the Canadian Rocky Mountains and Mackenzie Mountains. Morphologically, Hiscobeccus is distinguished from the other two genera by its open delthyrium in the pedicle valve. Early forms of Hiscobeccus show close morphological similarity to Rhynchotrema in their non-globular biconvex shells covered by strong growth lamellae only in the anterior portions. It has been suggested that Hiscobeccus evolved from the Rhynchotrema wisconsinense stock through increase in shell size, globosity, and strength of growth lamellae. Earliest species of Rhynchotrema has been documented convincingly from rocks of early Trentonian age, and the derivation of Hiscobeccus most likely took place during the mid-Trentonian. Lepidocyclus and Hypsiptycha evolved from either Rhynchotrema or Hiscobeccus by developing a pair of deltidial plates covering the delthyrium.

Rhynchotrema and other rhynchonellids that evolved before mid-Trentonian time are common to the North American (Laurentian) and the Siberia-Kazakhstan paleocontinents. In contrast, Hiscobeccus, Lepidocyclus, and Hypsiptycha that evolved after the mid-Trentonian are virtually restricted to Laurentia. Therefore, Rhynchotrema marked the last successful intercontinental migration of rhynchonellids during their Llandeilian-Caradocian cosmopolitanism. The pronounced provincialism of the North American Lepidocyclus fauna may have been caused by a number of factors. Facies control is not likely the explanation because these rhynchonellids occur in nearly all the inland and marginal platform seas of Laurentia and commonly are found together in the same types of rocks. Plate tectonics and sea-level changes are considered major causes. The Ordovician rhynchonellids lived in shallow marine (intertidal-subtidal) environments and were incapable of crossing vast, deep oceanic barriers because of their sedentary mode of life and short-lived motile larval stages. The widening of the ocean between North America and Siberia, coupled with high sea-level stand, may have created a sufficiently wide oceanic barrier to interrupt faunal mixing between the two paleocontinents by late Trentonian time. Moreover, the rise in sea level would have resulted in the disappearance of island faunas, which could have served as stepping stones for intercontinental migration of shallow-water benthic faunas during low sea-level stand. 